\title{
“Modeli molekula” Drage Grdenića i početci strukturne kemije u Hrvatskoj
}

\section{N. Raos}

Institut za medicinska istraživanja i medicinu rada, Ksaverska cesta 2, p.p. 291, 10001 Zagreb

\begin{abstract}
Sažetak
Početak strukturne kemije u Hrvatskoj može se smjestiti u 1948. godinu kada se Drago Grdenić (1919. - 2018.) vraća sa stručnog usavršavanja na Moskovskom sveučilištu (kod Nesmejanova i Kitajgorodskija) u Zagreb i gdje osniva 1952. Zavod za opću i anorgansku kemiju Prirodoslovno-matematičkog fakulteta. Pedesetih godina uspostavlja se suradnja i s Dorothy C. Hodgkin (Sveučilište u Cambridgeu). Zavod se poglavito bavi spojevima žive, potom molibdena, vanadija te organskim spojevima, posebice azitromicinom i njegovim derivatima. U radu je posebno obrađena Grdenićeva knjiga "Modeli molekula" (1950.), koja je formalno bila napisana kao priručnik za upotrebu kalotnih (Stuartovih) modela tvrtke Učila, no na svoje 142 stranice dala je pregled atomske teorije, stereokemije i strukturne kemije, čime je otvorila put modernoj kemiji u hrvatske škole.
\end{abstract}

Ključne riječi

Drago Grdenić, Dorothy C. Hodgkin, Sveučilište u Zagrebu, molekularni (Stuartovi) modeli, rendgenska difrakcijska analiza

\section{Uvod}

Poslijeratne godine danas doživljavamo kao godine represije i komunističkog terora, neimaštine i bijede. No bile su to i godine poleta, vjere u budućnost i nesmiljenog optimizma - jer kako bilo da bilo, ne može biti gore nego što je bilo: mir je uvijek bolji od rata. ${ }^{1}$ Ali nije samo to bio uzrok optimizmu, kraj rata i početak novog, komunističkog poretka koji je, barem u početku, mnogo obećavao.

Ratni napor donio je u civilni prostor nova znanstvena i tehnička dostignuća: deterdžente (Nilu i Plavi radion), plastične mase (najlon i polivinil), električne kućanske aparate (električni lonac i sl.), posuđe od aluminija, "metala budućnosti" o kojem se dotad jedino čulo da se rabi u proizvodnji aviona (slika 1). To je novo znanstveno-tehničko doba kulminiralo rješavanjem strukture DNA (1953.) $)^{2} \mathrm{i}$ Međunarodnom geofizičkom godinom 1957/58, ${ }^{3,4}$ koja je okrunjena 4. listopada 1957. lansiranjem prvog umjetnog satelita, sovjetskog Sputnika I.

Jugoslavenska i hrvatska znanost doživljava procvat jer je trebalo industrijalizirati i naoružati zemlju. $U$ to vrijeme, reče Drago Grdenić, "tražila se korist od znanosti. Za mene je to bila primijenjena kristalografija".${ }^{5}$ Raste industrija, napose kemijska. Već 1947. dostiže predratnu proizvodnju, 1956. ukupna je proizvodnja 3,5 puta, a osnovnih kemikalija (sumporne i dušične kiseline, sode, superfosfata i sl.) dva do šest puta veća od proizvodnje u predratnoj 1939. godini. ${ }^{6,7}$ Niču novi instituti, 1948. godine Institut za medicinska istraživanja i medicinu rada ("Rijetke su takve ustanove u svijetu u kojima se naučni radnici tako iskreno i predano bore za bolje uslove rada, što je uostalom moguće samo u našoj socijalističkoj zemlji".), ${ }^{8}$ Institut Ruđer

*Dr. sc. Nenad Raos

e-pošta: raos@imi.hr

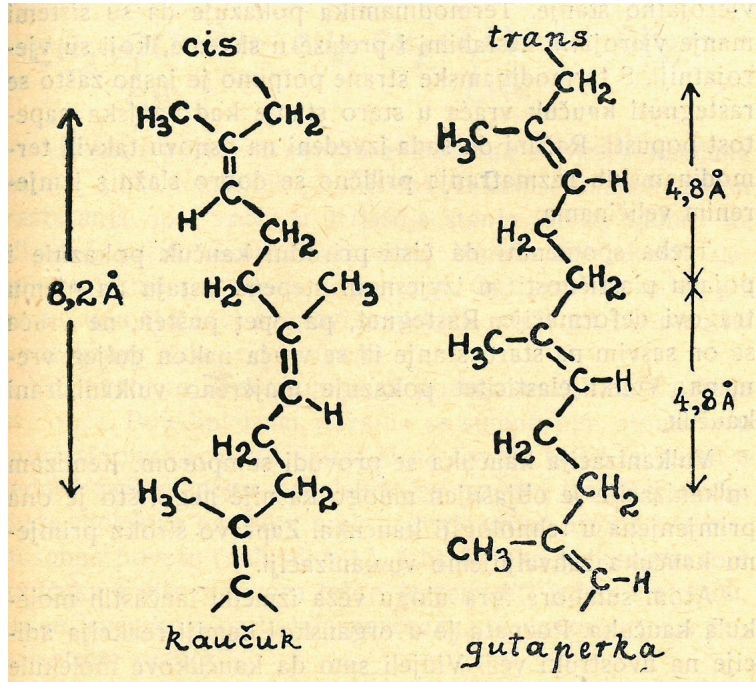

SI. 16. Kemijske strukturne formule dijelova kaucukove i gutaperkine molekule, koje objašnjavaju razliku izmedu tih dviju tvarı.

Slika 1 - Novo doba doba je polimera, ali ni polimeri se ne mogu razumjeti bez stereokemije i strukturne kemije (ilustracija iz Grdenićeve knjige "Divovske molekule", ref. 39, str. 43)

Fig. 1 - New age is the age of polymers, but polymers cannot be properly understood without the knowledge of stereochemistry and structural chemistry (from Grdenić's book "Giant Molecules", Ref. 39, p. 43)

Bošković (1950.) i - što je najvažnije za temu ovoga članka - 1952. godine osniva se Zavod za opću i anorgansku kemiju Prirodoslovno-matematičkog fakulteta Sveučilišta u Zagrebu, fakulteta koji se 1946. odcijepio od zagrebačkog Filozofskog fakulteta. ${ }^{9}$ Godine 1960. osniva se pet Sveuči- 
lišnih instituta, za fiziku (M. Paić), za fizikalnu kemiju (M. Karšulin, B. Težak), za anorgansku i analitičku kemiju (D. Grdenić), za organsku kemiju i biokemiju (K. Balenović) te za botaniku (S. Horvatić). Na Institutu Ruđer Bošković gradi se 1950. godine "domaćom pameću" ciklotron, ${ }^{10}$ kao dio programa izrade nuklearnog oružja, ${ }^{11,12}$ koji se međutim prikrivao razvojem nuklearne tehnologije za mirobljubljive svrhe. ${ }^{*}$ Novim "naučnim kadrovima" nastoji se pružiti što bolja naobrazba, na najboljim inozemnim institutima i sveučilištima:

Kada se spomenu učenjaci onda ljudi i nesvijesno pomišljaju na ćelave profesore s naočarima do pola nosa i sa sijedom bradom. Oni ne smiju imati smisla ni za kakvu šalu ili igru i moraju biti rastreseni. Ipak, to nije tako. Kad uđete u naš Institut, vidjet ćete da mladost dominira... Članovi ove grupe boravili su izvjesno vrijeme na specijalizaciji u inozemnim institutima. Neki su bili kod prof. Heisenberga, a neki drugi kod Bohra, Rosenfelda i drugih. ${ }^{13}$

Cvjeta popularizacija znanosti, ${ }^{14}$ jer "narodna vlast" nastoji nova znanstvena otkrića približiti najširoj publici, pa uz već tradicionalnu Prirodu (izlazi od 1911. godine) redovito izlaze znanstveno-popularni časopisi Otkrića, Savremena tehnika, Zemlja i svemir (danas: Čovjek i svemir), ABC tehnike, a Hrvatsko prirodoslovno društvo i Zagrebačka zvjezdarnica izdaju niz brošura posvećenih svim područjima prirodnih znanosti. ${ }^{15,16}$ To opet ne znači da znanstvenici nisu, kao i drugi građani socijalističke Jugoslavije, bili prigodice žrtve političke represije. ${ }^{17,18}$ Kao i u prošlom političkom sustavu, Kraljevini Jugoslaviji, znanstvenici su trebali, posebice ako su bili na sveučilištu, biti politički podobni za režim koji ih je zaposlio. ${ }^{* *}$ Građanska hrabrost je uostalom rijetka vrlina: češća je "kooperativnost" i - šutnja. ${ }^{19}$

"Znanost u Hrvatskoj, posebno kemijska, morala je poslije 1918. i 1941. krenuti ispočetka", piše Krešimir Balenović (1914. - 2003.), profesor organske kemije na PMF-u. "Zbog ignorancije, kemijska znanost mora se sada razvijati između dvije apsurdne skrajnosti, s jedne strane sindikalnog prakticizma, a s druge, marksističkog teoretičarenja ukrašenog 'kvantnom teorijom strukture materije $"$ ". ${ }^{20}$ Bila je to, prema Balenovićevim riječima, posljedica "agresivnosti ignoranata", koji su znanošću htjeli "pokrenuti zamašnjak proizvodnje", a da za to nisu osigurali prave uvjete, kako materijalne tako i stručne. Bila je to, kako se onda znalo reći, ostvarenje ciljeva "partizanskim metodama", a za nositelje se takve politike govorilo, sjećam se, da su "došli iz šume". Na kraju se hrvatska (jugoslavenska) znanost, napose kemija, pretvorila dobrim dijelom u "dekoraciju" novog poretka, kako je to u privatnom razgovoru znao reći Vladimir Simeon (1939. - 2017.), profesor zagrebačkog PMF-a. Primjena rezultata znanstvenih istraživanja u proizvodnji

\footnotetext{
* "Nije daleko vrijeme kad će se zemlje u svijetu dijeliti na one koje se koriste i one koje se ne koriste nuklearnom energijom. A budući da mi ne želimo da zauvijek ostanemo zaostala zemlja, hoćemo da se nuklearnom energijom koristimo i koristit ćemo se njome isključivo u mirnodopske svrhe" (J. B. Tito pri posjetu Nuklearnom institutu "Boris Kidrič" u Vinči kraj Beograda; Savremena tehnika 6 (6) (1955) 237-238).

${ }^{* *}$ U Kraljevini Jugoslaviji sveučilišni su profesori na fakultetu bili unitaristi, pa i masoni, poput članova kraljevske kuće. U novoj Jugoslaviji bilo je pak poželjno da budu komunisti i sudionici NOB-a, a usto poslušni trenutačnoj državnoj politici ("biti na partijskoj liniji").
}

postajala je sve teža, ${ }^{21}$ a nedostatak jasne vizije u znanstvenoj politici dovodio je do teoretiziranja i prepucavanja. ${ }^{22,23}$

\section{Put u sovjetsku Rusiju}

Masovno školovanje mladih znanstvenika u inozemstvu nije bila posljedica samo razložne želje da se znanost $u$ Jugoslaviji digne na jednu višu, pravo rečeno, industrijsku razinu (koja je bila potrebna radi obnove i "socijalističkog razvoja" zemlje) nego i zato što je rat ostavio svoje tragove kako na materijalnoj tako i na organizacijskoj te kadrovskoj strukturi sveučilišta. Mnogi su sveučilišni nastavnici bili, s pravom ili nepravom, kompromitirani zbog suradnje s ustaškim režimom ("okupatorom i njegovim slugama"). Drugi je problem bio što su dolaskom nove vlasti svi akti one stare postali ništavni, pa je tako primjerice Farmaceutsko-biokemijski fakultet osnovan dvaput: 1942. i 1945. godine. ${ }^{24}$

Jedan od tih mladih znanstvenika koji su se školovali u inozemstvu bio je i Drago Grdenić (1919. - 2018.), što je urodilo najdalekosežnijim posljedicama za našu sredinu. "Njegov boravak u Moskvi od 1946 do 1948 godine...", piše u knjižici o Zavodu za opću i anorgansku kemiju, ${ }^{25}$ "odredio je u velikoj mjeri ondašnji i sadašnji znanstveni profil Zavoda". Milan Sikirica još je jasniji:

Kineska poslovica kaže da svako putovanje započinje prvim korakom. Tako je i roentgenska strukturna analiza na brdovitom Balkanu započela u listopadu 1946. putovanjem prof. Grdenića u Moskvu. Kemiju organoživinih spojeva učio je od A. N. Nesmejanova (1899. - 1980.) čije je tumačenje veze u organskim spojevima 1949. bilo politički osuđeno kao zapadnjačko, buržoasko i nazadno. ${ }^{26}$

Grdenićevo zanimanje za živine spojeve počelo je početkom 1942. godine kada je kao diplomand dobio mjesto kod Tomislava Pintera (1899. - 1980.), tada asistenta i honoranog predavača na zagrebačkom Medicinskom fakultetu. ${ }^{27,28}$ Pinter je otkrio katalitičko djelovanje živinih iona na razgradnju heksacijanoferata(II), pa je tu reakciju htio upotrijebiti za kolorimetrijsko određivanje tragova žive, prije svega u urinu. No tu se pojavilo pitanje strukturne formule živinog acetamida, koju je njegov student trebao dokazati reakcijom metiliranja diazometanom, no dobiveni produkt nije istražio jer je 1942. otišao u partizane - i tako za dugo vremena prekinuo započeto istraživanje (strukturu živina acetamida riješio je istom 1969. godine $\left.^{29}\right)$.

Nakon rata, nakon kraćeg zaposlenja na Višoj pedagoškoj školi u Splitu, vraća se u studenome 1945. u Zagreb, no ovaj put na Kemijski odsjek Filozofskog fakulteta (Prirodoslovno-matematički fakultet još nije bio osnovan), kao asistent profesora Gilberta Flumianija (1889. - 1976.), nastavljajući istraživati reakciju živina acetamida s diazometanom. Tu mu se pružila prilika za usavršavanje u inozemstvu, no samo u Sovjetskom Savezu:

Nekoliko godina nakon rata nije bilo mogućnosti za postdiplomski studij na jednom od zapadnoeuropskih ili američkih sveučilišta, a izgledi za takav studij na sovjetskim sveučilištima bili su veoma mali. Ipak, pripremao sam se za odlazak 
u Moskvu, i prije svega, proučavao priopćenja o istraživanjima organoživinih spojeva koja je vodio profesor i akademik Aleksandr Nikolajevič Nesmejanov (1899. - 1980.) u Institutu organske kemije Sovjetske akademije znanosti kojem je bio na čelu. Upućenost u njegovo područje, kao i moje iskustvo u radu sa živinim acetamidom i otkriće merkuriranog diazometana, smatrao sam najboljom preporukom profesoru Nesmejanovu da me primi za suradnika. ${ }^{27,28}$

Grdenić je imao sreće, pa se u listopadu 1946. uputio u Moskvu profesoru Nesmejanovu. No kada se profesor upoznao s pravim interesom svojega studenta, uputio ga je kolegi s Instituta Aleksandru Isaakoviču Kitajgorodskiju (1914. - 1985.). On ga je uputio u tajne rendgenske strukturne analize, koja se tek tada počela pod njegovim vodstvom razvijati na Moskovskom sveučilištu. "I u Moskvi mi je bilo lijepo, makar u teškim poslijeratnim uvjetima života," prisjeća se Grdenić. "Ljudi u Institutu bili su zaljubljeni u znanost. Nakon povratka u Zagreb nastojao sam strukturnu analizu uvesti na PMF." ${ }^{\prime 30}$

Ta mu se želja ispunila jer je nakon povratka iz Moskve našao mjesto u Fizičkom institutu, Laboratoriju za rentgenske zrake, koji je posjedovao uređaj za radiografiju i analizu polikristalnog uzorka Debey-Scherrerovom metodom, što ga je još 1938. godine nabavio tadašnji predstojnik Zavoda Stanko Hondl (1873. - 1971.). No prava je strukturna kemija počela u Hrvatskoj 1948. kada je Fizičkom insti- tutu došla preko engleske donacije kamera Unicam S25. Ona je omogućila snimanje rendgenograma monokristalnih uzoraka, pa stoga i određivanje molekularnih struktura. Tim je uređajem na Staru godinu 1948. Grdenić snimio prvi difraktogram - difraktogram natrijeva klorida. Grdenić je doktorirao 1951. da bi godinu dana nakon toga osnovao Zavod za opću i anorgansku kemiju PMF-a. ${ }^{31}$ Nakon Grdenićeva polugodišnjeg boravka na Sveučilištu u Oxfordu (1955./1956.), kod Dorothy C. Hodgkin (1910. - 1994.), koja je poslije, 1964. godine dobila Nobelovu nagradu, počela je intenzivna i vrlo plodonosna suradnja Zavoda s tim uglednim sveučilištem.

"Primjenom difrakcije rendgenskih zraka došli su kemičari do pouzdanog znanja o građi tvari, bio to kemijski spoj ili materijal cijenjen zbog svojih svojstava", piše Grdenić. "Bez strukturne analize difrakcijom rentgenskih zraka, kemija ne bi bila toliko uspješna znanost kakva je danas". ${ }^{32}$ No ne samo to. Nova je metoda donijela i novu kemiju - kemiju struktura umjesto kemije formula. Za to nije bilo dovoljno imati samo dobre instrumente, pa čak ni dobro obučene kemičare koji se znaju njima služiti. Trebalo je sa strukturom molekula i kristala upoznati najširi krug kemičara, pa i one koji se s kemijom u poslu i životu samo uzgred susreću. U tome je Grdeniću poslužio talent za pisanje, kojim se obilno koristio u promociji strukturne kemije u našoj sredini. Pripomoglo je i opće zanimanje javnosti za atome i molekule - jer "danas se svuda govori o atomima". ${ }^{33}$

Tablica 1 - Kratka povijest rendgenske difrakcijske analize, napose u Hrvatskoj

Table 1 - A short history of X-ray analysis, especially in Croatia

\begin{tabular}{|c|c|}
\hline Godina & Događaj \\
\hline 1895. & Njemački fizičar Conrad Rönten (1845. - 1924.) otkriva novu vrstu zračenja koje naziva "X-Strahlung". \\
\hline 1912. & $\begin{array}{l}\text { Njemački fizičar Max von Laue (1879. - 1960.), Nobelova nagrada za fiziku 1914., dokazuje valna svojstva } \\
\text { rendgenskog zračenja ogibom na kristalu bakrova(II) sulfata pentahidrata. }\end{array}$ \\
\hline 1913. & $\begin{array}{l}\text { Otac Sir William (1862. - 1942.) i sin William Lawrence Bragg (1890. - 1971.) rješavaju prvu kristalnu strukturu, } \\
\text { strukturu dijamanta, a neposredno potom sfalerita i pirita. }\end{array}$ \\
\hline 1938. & U Zagreb dolazi prvi uređaj za difrakcijsku analizu - praha. \\
\hline 1948. & $\begin{array}{l}\text { Izlaze prve knjižice (D. Grdenić) posvećene strukturnoj kemiji, "Rendgenske zrake u nauci i tehnici" } \\
\text { i "Divovske molekule". }\end{array}$ \\
\hline 1948. & U Zagreb dolazi kamera Unicam S25 koja omogućuje snimanje difraktograma monokristala. \\
\hline 31. 12. 1948. & D. Grdenić snima u Zagrebu prvi difraktogram monokristala ( $\mathrm{NaCl})$. \\
\hline 1950. & D. Grdenić izmjerio duljinu veze $\mathrm{Hg}-\mathrm{Cl}$; prva kristalna struktura riješena u Zagrebu. \\
\hline 1950. & Izlazi knjiga "Modeli molekula" (D. Grdenić). \\
\hline 1951. & $\begin{array}{l}\text { Objavljena prva potpuna kristalna struktura riješena u Zagrebu (D. Grdenić): 1,7-dioksa-4,10-dimerkuraciklododekan. } \\
\text { Prvi zapis kristalne strukture iz Jugoslavije u Cambridge Structural Database (Acta Cryst. } 5 \text { (1952) 367). }\end{array}$ \\
\hline 1951. & Na IRB-u započinju istraživanja rendgenskom strukturnom analizom; kupljen Weissenbergov goniometar. \\
\hline 1953. & $\begin{array}{l}\text { James Dewey Watson (r. 1928.) i Francis Crick (1916. - 2004.) rješavaju strukturu DNA iz difraktograma } \\
\text { koji je snimila Rosalind Franklin (1920. - 1958.). }\end{array}$ \\
\hline 1953. & U Zagrebu riješena struktura organskog spoja bez upotrebe metode teškog atoma (ftalilurea, $\mathrm{C}_{9} \mathrm{H}_{6} \mathrm{~N}_{2} \mathrm{O}_{2}$ ). \\
\hline 1953. & Riješena prva struktura uz upotrebu Weissenberogova goniometra (IRB): $(\mathrm{ClHg})_{3} \mathrm{O}^{+} \mathrm{Cl}^{-}$. \\
\hline 1954. & D. Grdenić sudjeluje na Kristalografskom kongresu u Parizu. Tamo upoznaje D. C. Hodgkin. \\
\hline 1960. & $\begin{array}{l}\text { Pattersonovom metodom teškog atoma riješene prve strukture proteina. John Kendrew (1917. - 1997.) rješava } \\
\text { strukturu mioglobina, a Max Ferdinand Perutz (1914. - 2002.) strukturu hemoglobina. }\end{array}$ \\
\hline 1966. & $\begin{array}{l}\text { Osnovan pri JAZU (danas HAZU) Jugoslavenski centar za kristalografiju. } \\
\text { Centar je iste godine primljen u Međunarodnu kristalografsku uniju. }\end{array}$ \\
\hline
\end{tabular}


Tablica 1 - (nastavak)

Table 1 - (continued)

\begin{tabular}{|c|c|}
\hline Godina & Događaj \\
\hline 1963. & Na IRB-u riješena prva struktura iz rendgenograma praha intermetalnog spoja $\mathrm{U}_{4} \mathrm{Mo}_{5} \mathrm{Si}_{3}$. \\
\hline 1966. & D. C. Hodgkin nakon dodjele Nobelove nagrade (1964.) posjećuje Zagreb i zagrebačke kristalografe. \\
\hline 1971. & $\begin{array}{l}\text { Otvoren Sveučilišni računski centar (SRCE) s računalom UNIVAC 1101, koje je omogućilo, između ostalog, } \\
\text { kompjutorsko rješavanje kristalnih i molekularnih struktura. }\end{array}$ \\
\hline 1973. & $\begin{array}{l}\text { Izlazi prvi udžbenik kristalokemije na hrvatskom jeziku, "Molekule i kristali” (D. Grdenić). } \\
\text { Knjiga je doživjela pet izdanja. }\end{array}$ \\
\hline 1973. & $\begin{array}{l}\text { U Trstu je održana prva konferencija u organizaciji Jugoslavenskog centra za kristalografiju i Talijanske kristalografske } \\
\text { zajednice. Otada se konferencije održavaju svake treće godine naizmjence u Hrvatskoj (jednom u Sloveniji) i u Italiji. }\end{array}$ \\
\hline 1973. & $\begin{array}{l}\text { U Boredeauxu održan prvi sastanak europskih kristalografa. Boris Kamenar (1929. - 2012.) obnaša dužnost } \\
\text { podpredsjednika, a potom predsjednika Europskog kristalografskog odbora. }\end{array}$ \\
\hline 1974. & Na Zavodu za opću i anorgansku kemiju nabavljen je četverokružni automatski difraktometar Philips PW1100. \\
\hline 1974. & $\begin{array}{l}\text { Određena struktura molibdenilova(VI) acetilacetonata. } \\
\text { Time počinje program istraživanja molibdenovih kompleksa u Zagrebu. }\end{array}$ \\
\hline 1974. & Riješena struktura tetrakis(trifluoracetatoživa)metana, koja je postala ikonom zagrebačke kristalografije. \\
\hline 1976. & $\begin{array}{l}\text { Ivan Vicković (r. 1945.) uvodi programe za kompjutorsko rješavanje kristalne strukture; } \\
\text { 1977. riješene su prve strukture kompjutorom UNIVAC } 1101 \text { (SRCE). }\end{array}$ \\
\hline 1986. & Riješena struktura dvaju derivata azitromicina (Sumameda). \\
\hline 1988. & Riješena struktura samog azitromicina (aktivne molekule). \\
\hline 1990. & U Sisku održana posljednja, 25. Konferencija Jugoslavenskog centra za kristalografiju. \\
\hline 1991. & Jugoslavenski centar za kristalografiju prestao s radom; umjesto njega osniva se Hrvatska kristalografska zajednica. \\
\hline 1994. & U Zagrebu riješena prva struktura miješanih kompleksa molibdena i vanadija, polioksomolibdovanadata. \\
\hline 1996. & $\begin{array}{l}\text { U zagrebačkom Tehničkom muzeju održana izložba "Ljepota molekulskih struktura" (N. Raos). } \\
\text { Bila je to prilika da hrvatski i svjetski znanstvenici prikažu rezultate svojih istraživanja struktura molekula najširoj publici. }\end{array}$ \\
\hline
\end{tabular}

\section{“Modeli molekula"}

Ako strukturna kemija počinje u Zagrebu (Hrvatskoj) povratkom Grdenića 1948. iz Moskve, onda učenje strukturne kemije počinje 1950. izlaskom njegove knjige, u zamjetnoj nakladi od 5000 primjeraka, "Modeli molekula" (slika 2). ${ }^{34}$ To na prvi pogled zbunjuje, jer ta knjižica djeluje kao nastavak već objavljenih "Atoma i molekula" 33 iz 1946., a s druge strane kao početak puta prema "Povijesti kemije"$^{\prime 32}$ iz 2000. godine. No namjena joj je bila drugačija. "Atomi i molekule" bavi se prije svega strukturom atoma i nuklearnom energijom jer "u jezgrama atoma nagomilane su goleme zalihe energije - govore učenjaci i obećavaju budućim pokoljenjima krasan život i neslućene mogućnosti razvoja". ${ }^{33}$ Namjena te druge knjižice, "Modeli molekula" posve je prozaična - i praktična. Već se naime iz prvih rečenica Predgovora (str. 5) vidi njezina svrha: "Usporedo s ovom knjižicom dobivaju naši nastavnici i đaci prave, moderne modele molekula za sastavljanje. Zbog njih je ova knjižica i napisana." Drago Grdenić je naime u suradnji s tvrtkom Učila izradio kalotne modele koje je trebalo prodavati po školama.* Stoga bismo tu knjižicu mogli shvatiti kao priručnik s uputama uz kupljene modele.

\footnotetext{
* Komplet se sastojao od 40 spojnica i 50 kuglica: $6 \mathrm{C}\left(\mathrm{sp}^{3}\right)$, $8 \mathrm{C}\left(\mathrm{sp}^{2}\right)$, $2 \mathrm{C}(\mathrm{sp}), 18 \mathrm{H}, 6-\mathrm{O}-, 4 \mathrm{O}=, 2 \mathrm{Cl}, 2 \mathrm{~N}$ (amino), $2 \mathrm{~N}$ (nitro); ref. 34, str. 136. Mjerilo: $2 \mathrm{~cm}=1 \AA\left(2 \cdot 10^{8}: 1\right)$.
}

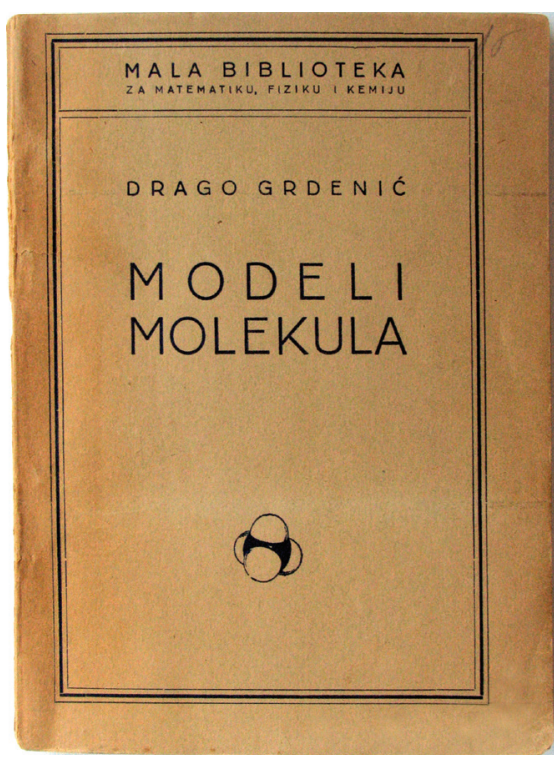

Slika 2 - Naslovna stranica Grdenićeve knjige "Modeli molekula", 1950. $(16,7 \times 11,7 \mathrm{~cm})$

Fig. 2 - Title page of Grdenićs book "Modeli molekula" (Models of Molecules), 1950, $(16,7 \times 11,7 \mathrm{~cm})$

No kada se pogledaju "Modeli molekula" u cjelini, vidi se da su kalotni (Stuartovi) modeli poslužili autoru tek kao 
povod da se raspiše o molekulama i njihovim strukturama. Da je tako, jasno govori podatak da se od devet poglavlja na 142 stranica knjige samo posljednje (na 14 stranica!) bavi opisom kalotnih modela te uputama za njihovo sastavljanje (slika 3). U drugim poglavljima piše o strukturi atoma i molekula, stereokemiji, kemijskoj vezi (ionskoj i kovalentnoj), Lewisovim strukturama, unutrašnjim vibracijama molekula, pa čak i o kinetičkoj teoriji plinova - iz koje slijedi dokaz za realno postojanje molekula (slika 4). Sve u svemu, riječ je o popularno napisanom udžbeniku suvremene kemije. To se vidi već iz Predgovora (str. 5/6):

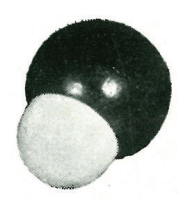

Klorovodik $\mathrm{HCl}$

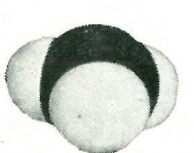

Amonijak $\mathrm{NH}_{3}$

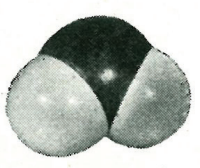

Voda $\mathrm{H}_{2} \mathrm{O}$

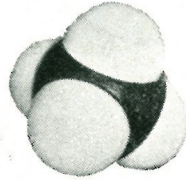

Metan $\mathrm{CH}_{4}$

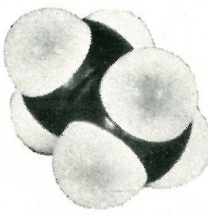

Etan $\mathrm{H}_{3} \mathrm{C} \mathrm{CH}_{3}$

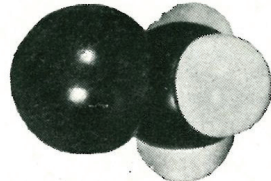

Metil-klorid $\mathrm{CH}_{3} \mathrm{Cl}$

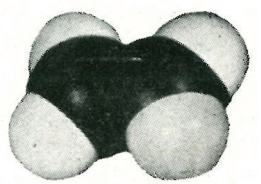

Etîlen $\mathrm{H}_{2} \mathrm{C}: \mathrm{CH}_{2}$
Tabla I

Slika 3 - Kalotni (Stuartovi) modeli jednostavnih anorganskih i organskih spojeva ("Modeli molekula", nasuprot str. 136)

Fig. 3 - Stuart models of simple inorganic and organic compounds ("Modeli molekula", facing p. 136)

Uspjeh nastavnika kemije zavisi od toga, kako je predavao osnovne pojmove kemije. Ti osnovni pojmovi su pojam kemijskog spajanja i pojam molekule. Do tih se pojmova ne dolazi lako. Treba uvijek imati na umu, da su ti pojmovi zapravo i bili "kamen mudraca", što su ga alkemičari tra-

\footnotetext{
*Izlaganje atomske teorije dalo je Grdeniću povoda da se obrecne, što je onda bilo vrlo popularno, na "idealiste" braneći dakako dijalektičko-materijalistički (marksistički) pogled na svijet: "Najjači biljeg natražnjaštva i protivnaučnog stava u odnosu prema napretku prirodnih nauka u 19 . stoljeću nosi idealitička filozofija fizičara E. Macha (1838. - 1916.). Sljedbenici mahizma među prirodoslovcima poricali su postojanje atoma ili, u manjoj mjeri, negirali svaku mogućnost da o postojanju atoma bilo što doznamo" Potom se obrušio na Ostwaldov energetizam: "Energija bez materije! Zaista idealističko shvaćanje, prekriveno prirodnonaučnom terminologijom" (ref. 34, str. 39/40). Marksisti su općenito imali negativan stav prema "nedijalektičkim" oblicima materijalizma, mehanicizmu i energetizmu, smatrajući ih ili naivnima (mehanicizam) ili pak nedostatnim simplifikacijama (energetizam).
}

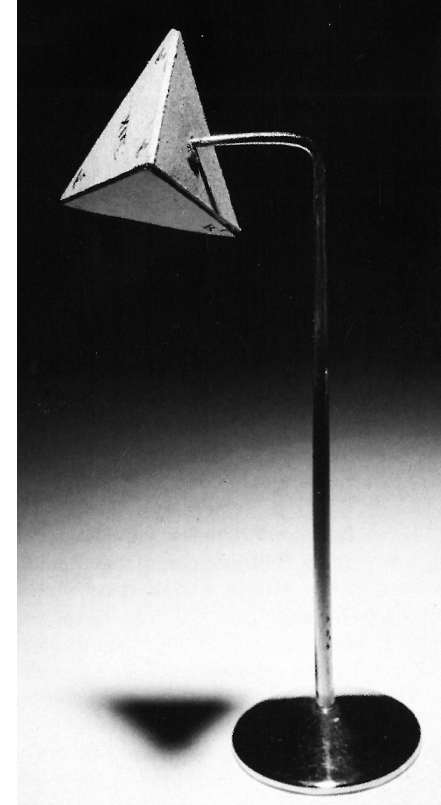

Slika 4 - Van't Hoffov molekularni model od papira iz 1906. godine (Deutsches Museum, München). "Biografi van't Hoffa pričaju, da su njegovi tetraedrijski modeli toliko oduševili brazilijanskog kralja Don Pedra, koji se u svom slobodnom vremenu bavio kemijom, da ih je svuda propagirao i zahtijevao, da se izrađuju iz drva i stave u prodaju, da bi se svaki učenik još zarana naučio prostorno shvaćati molekule" ("Modeli molekula", str. 18).

Fig. 4 - Van't Hoff"s molecular paper model, 1906 (Deutsches Museum, München). "Van't Hoff's biographers had reported that Brazilian king Don Pedro, who enjoyed chemistry in his spare time, was so excited with his (Van't Hoff's) tetrahedral models, that he promoted them everywhere and demanded them to be made of wood and put on the market so that every pupil at their very young age could learn how to comprehend molecules as spatial objects" ("Modeli molekula", p. 18).

žili. Kad je otkrivena zagonetka kemijskog spajanja, nađen je ključ za razumijevanje kemijskih pretvorbi, i alkemija je prerasla u kemiju. Stoljećima tražena tajna je nađena.

U tome i leži problem učenja kemije, poručuje autor, posebice one suvremene. Kemija je teška zbog formula, a one se ne mogu razumjeti ako se ne razumiju osnovni pojmovi: "Osnovi kemije - spajanje atoma i realnost molekula - nisu postali svojinom njihova intelekta, oni te pojmove nisu usvojili" (str. 6). Namjena knjižice je dakle da nastavnici, a potom i njihovi učenici usvoje te osnovne pojmove, pojmove "spajanje atoma i realnost molekula".

No kada govori o "spajanju atoma", Grdenić se ne zadržava na valenciji: "Pokazalo se, da ta crtica, koja simbolizira međuatomsku vezu u jednoj molekuli, ne mora značiti jednaku vezu u drugoj molekuli, pa i onda, kada se radi o istim atomima... Molekula se ispoljuje kao jedna cjelina, kao kompleks atoma sa svojom posebnom fizionomijom" (str. 13). Snaga moderne nauke je upravo u mjerenju udaljenosti između atomskih jezgri "u sitnim i nevidljivim molekulama" iz kojih potom izvodi zaključke o svojstvima tvari (str. 14). 
Najveća vrijednost Grdenićeve knjige je upoznavanje čitatelja s metodama i rezultatima rendgenske strukturne analize sa željom da te metode i rezultati postanu normalan dio nastavnog programa već na srednjoškolskoj razini. I to autor čini na vrlo jednostavan, jasan i nadasve popularan način, uz minimalnu upotrebu fizičkih modela i matematičkih formula (str. 122):

Kako smo već rekli, rentgenske zrake rasijavaju se na elektronima. Dosta složenim putem može se iz rentgenskih interferencijskih maksimuma dobiti raspored elektrona u kristalu. Rezultat je upravo gustoća elektronskog oblaka kao funkcija mjesta u elementarnoj ćeliji kristalne rešetke. Drugim riječima, rentgenska metoda primijenjena na molekularne rešetke daje kao rezultat elektronski raspored u molekuli, elektronski oblak jedne cijele molekule.

Kao primjer daje potom strukturu racemične vinske kiseline (slika 5) koja je određena tek prije godine dana (G. S. Parry 1949!). "Prije svega van't Hoffova 'kemija u prostoru' ovdje trijumfira u punom sjaju", piše Grdenić (str. 125). "Ono, što sam van't Hoff nikada nije ni mislio, 'fotografirano' je tako reći rentgenskim zrakama." Potom navodi i raspored elektrona u kristalnoj strukturi naftalena odajući pritom priznanje Kekuléu koji je došao do iste strukture indirektnim metodama, u doba kada su atomi i molekule bile tek hipotetičke čestice. Ono što će svakako začuditi suvremenog čitatelja je autorova konstatacija (str. 128) da su kemijske metode određivanja strukture organskih spojeva još najpouzdanije, mada ne i najbrže. U njegovo se vrijeme još moglo reći kako "fizičke i kemijske metode za određivanje strukture molekula s velikim se uspjehom nadopunjavaju" (str. 128) - no autor očito nije mogao gledati u budućnost pa znati da će fizičke metode već za njegova života potpuno istisnuti one kemijske. Još je manje mogao predvidjeti da će kompjutorska grafika istisnuti modele molekula ${ }^{35}$ unatoč tome što oni "vrlo dobro odgovaraju pravom stanju stvari - realnim molekulama".

\section{Zaključak}

Pitanje koje se nužno nameće nakon čitanja ovog povijesnog osvrta je koliko hrvatska znanost zaostaje za svjetskom znanošću i s kolikim zaostatkom hrvatsko školstvo prati razvoj znanosti. Na prvo je pitanje lako odgovoriti. Nakon prvog određivanja kristalne strukture (1913.) trebalo je proteći 35 godina da bi se u Zagrebu 1948. snimio monokristal natrijeva klorida i 38 godina da bi se 1951 . riješila prva kristalna struktura (tablica 1). Sve je išlo beskrajno sporo. Pet godina je trebalo da se programi za određivanje kristalne strukture instaliraju na zagrebačkom kompjutoru, UNIVAC 1101 (SRCE), što nas ne bi trebalo previše čuditi budući da je to računalo bilo živ primjer samoupravno-socijalističke nebrige i nemara. ${ }^{36}$ To se dakako odrazilo i u radu kristalografa, pa tako u godišnjem izvještaju čitamo kako su "u istraživanju adukata organoživinih

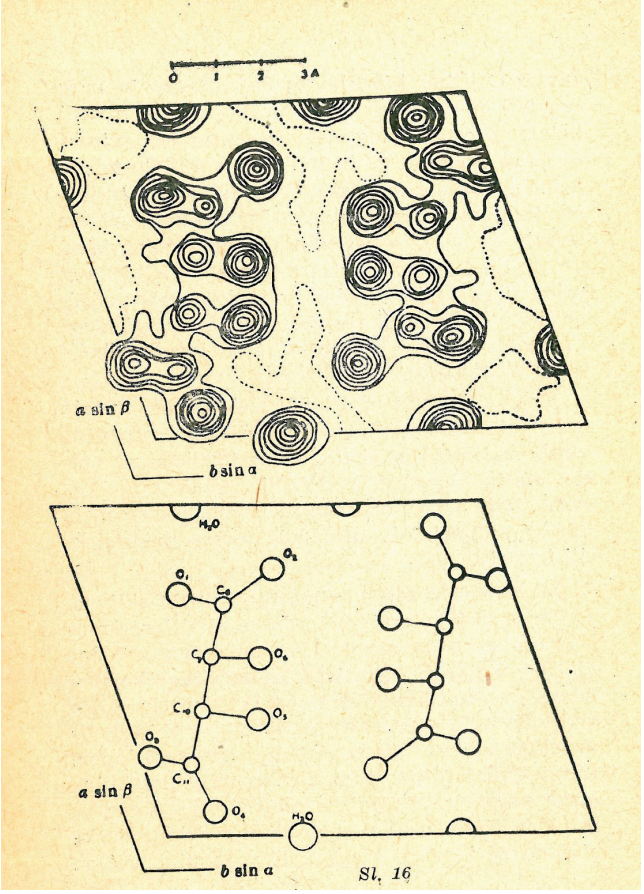

Slika 5 - Dijagram elektronske gustoće racemične vinske kiseline ("Modeli molekula", str.124)

Fig. 5 - Plot of electronic density of racemic tartaric acid ("Modeli molekula", p. 124)

spojeva priređeni ... ali rezultati nisu publicirani zbog zastoja u radu instrumenata (rezervni dijelovi) i zbog kvara i remonta kompjutora (SRCE)" ${ }^{37}$

Stoga nam povijest rendgenske strukturne analize u Zagrebu pruža pogled na neograniziranost znanstvenog rada u socijalističkom sustavu, no ujedno je i spomenik upornosti i predanosti hrvatskih kemičara. Liebigove riječi "Die Grundlage aller chemischen Arbeiten ist eine unermüdlische Geduld und eine Ausdauer ohne Grenzen (Temelj svakog kemijskog posla je neumorno strpljenje i ustrajnost bez granica)" vrijede i ovdje.

Drugo je međutim pitanje koliko treba da znanstveno otkriće iz znanstvenog časopisa dospije u udžbenike. Istraživanjem sadržaja hrvatskih udžbenika ustanovio sam da se prva Lewisova formula pojavila u srednjoškolskom udžbeniku istom 1947. da bi postala neizostavnim dijelom nastavnog programa 1963. - dakle 40 godina nakon što je 1923. Lewis objavio konačnu verziju svojega načina konstruiranja kemijske veze. ${ }^{38}$ Kako vidimo iz primjera "Modela molekula" trebao je skoro isto toliko vremena (od 1913. do 1950.) da se o rendgenskoj difrakcijskoj analizi i modelima molekula počne govoriti kao nečemu o čemu bi se trebalo učiti i u srednjoj školi. Koliko je pak trebalo da modeli molekula i rendgenska strukturna analiza dopru do udžbenika, trebalo bi istom istražiti. 


\section{Literatura \\ References}

1. M. Fugaš, Sjećanja prvog novog suradnika, u: N. Raos (ur.), IMI očima suradnika, Institut za medicinska istraživanja i medicinu rada, Zagreb, 1999., str. 33-37.

2. J. D. Watson, F. H. G. Crick, Molecular structure of nucleic acids: a structure for deoxyribose nucleic acid, Nature 171 (1953) 737-738, doi: https://doi.org/10.1038/171737a0.

3. M. Butorac, Međunarodna geofizička godina, Priroda 64 (6) (1957) 169-174

4. N. Raos, Međunarodna geofizička godina (1957./58.) - u Zagrebu, Priroda 98 (7-8) (2008) 13-15.

5. B. Kamenar, Sjećanja jednog kemičara, Bibilioteka Hrvatski kemičari i kemijski inženjeri (ur. D. Škare), knjiga 4, HDKI/ Kemija u industriji, Zagreb, 2011., str. 5.

6. Č. Jenić, Hemiska industrija, u: Enciklopedija Jugoslavije, 3 sv., Leksikografski zavod FNRJ, Zagreb, 1968., str. 668-669.

7. Kemijska industrija, u: Enciklopedija leksikografskog zavoda, sv. 4, Leksikografski zavod FNRJ, Zagreb, 1969., str. 173174.

8. Olakšanje rada ljudima. Uspjesi Instituta za higijenu rada Jugoslavenske akademije znanosti i umjetnosti u Zagrebu, Savremena tehnika 5 (6) (1954) 147-148.

9. I. Vicković (ur.), 50 godina Zavoda za opću i anorgansku kemiju Prirodoslovno-matematičkog fakulteta Sveučilišta u Zagrebu, Zavod za opću i anorgansku kemiju, Zagreb, 2002.

10. S. Kaučić, Zagrebački ciklotron, monografija, Institut Ruđer Bošković, Zagreb, 2006.

11. V. Pravdić, Nuklearni program Jugoslavije 1950-tih i 1960-tih godina. Sjećanja iz žablje perspektive, Encycl. Moderna 15 1(45) (1995) 31-39.

12. K. Pisk, Jugoslavenski nuklearni program i Institut Ruđer Bošković, u: Z. Benčić (ur.), Povijest i filozofija tehnike 7. simpozij PIFT 2018., Zagreb, 2018.

13. U Institutu "Rugjer Bošković", Savremena tehnika, 6 (8-9) (1955) 317-318.

14. N. Raos, Povijesni osvrt na popularizaciju kemije u Hrvatskoj, Kem. Ind. 61 (5-6) (2012) 281-288.

15. T. Kren, D. Roša (ur.), Spomenica Zvjezdarnice Zagreb 1903.-2003. povodom stote obljetnice, Zagrebački astronomski savez - Zvjezdarnica Zagreb, Zagreb, 2003.

16. J. Balabanić, M. Vuković, Hrvatsko prirodoslovno društvo. Ogled od 120. obljetnici osnutka (1885.-2005.), Prirodoslovlje 5 (1) (2005) 3-44.

17. M. Rac, A. Ž. Lovrić, Primjeri političkog onemogućavanja rada hrvatskih prirodoslovaca, 1. dio: profesori Ivo Horvat, Stjepan Bertović i Boris Vrtar, u: Radovi Leksikografskog zavoda "Miroslav Krleža", knj. 3, Leksikografski zavod "Miroslav Krleža", Zagreb, 1993., str. 223-240.

18. N. Trinajstić, Mladen Deželić - zaboravljeni hrvatski prirodoslovac, Ogledi o znanosti i znanstvenicima, Matica hrvatska, Zagreb, 1998., str. 31-49.

19. N. Raos, Bijeda akademske zajednice, Kem. Ind. 68 (9-10) (2019) 445.

20. K. Balenović, Lavoslav Ružička: Stara domovina i kemija u Hrvatskoj 1918. - 1988., Rad Jugosl. akad. znan. umjet., kem. 7 (443) (1989) 131-197.

21. N. Raos, Znanstvene institucije i razvojno-istraživačke organizacije kao nosioci organiziranog razvojno-istraživačkog i masovnog inventivnog rada, u: I. Mikulić (ur.), Zbornik radova sa savjetovanja "Inova 1985", Inventivni radnik, Zagreb, 1985., str. 132-134.

22. N. Zovko, Prilog raspravi o vrednovanju znanstvenog rada, Encycl. moderna 14 (2) (1993) 173-175.

23. N. Trinajstić, Experimental and theoretical research in the natural sciences, Encycl. moderna 14 4(44) (1993) 359-360.

24. Spomenica u povodu stote obljetnice osnutka studija farmacije na Sveučilištu u Zagrebu 1882.-1982., Farmaceutsko-biokemijski fakultet Sveučilišta u Zagrebu, Zagreb, 1983., str. 6

25. Zavod za opću i anorgansku kemiju Prirodoslovno-matematičkog fakulteta 1952.-1982., Zavod za opću i anorgansku kemiju Prirodoslovno-matematičkog fakulteta, Zagreb, 1982; citirano u: B. Kamenar, Suradnja sa znanstvenim središtima u zemlji i inozemstvu, u: I. Vicković (ur.), 50 godina Zavoda za opću i anorgansku kemiju Prirodoslovno-matematičkog fakulteta Sveučilišta u Zagrebu, Zavod za opću i anorgansku kemiju, Zagreb, 2002., str. 105-107.

26. M. Sikirica, Priče iz davnine, u: I. Vicković (ur.), 50 godina Zavoda za opću i anorgansku kemiju Prirodoslovno-matematičkog fakulteta Sveučilišta u Zagrebu, Zavod za opću i anorgansku kemiju, Zagreb, 2002., str. 47-54.

27. D. Grdenić, Mojih pedeset godina kemije, Kem. Ind. 49 (78) (2000) 317-337.

28. D. Grdenić, Mojih pedeset godina kemije, HDKI/Kemija u industriji, Zagreb, 2000.

29. D. Grdenić, B. Kamenar, The crystal structure of mercury(II) acetamide, Inorg. Chim. Acta 3 (1969) 25-28.

30. N. Zlatković, Akademik Drago Grdenić (intervju), Priroda 94 (4) (2004) 6-8.

31. D. Grdenić, U povodu 50. Obljetnice Zavoda za opću i anorgansku kemiju Prirodoslovno-matematičkog fakulteta Sveučilišta u Zagrebu, u: I. Vicković (ur.), 50 godina Zavoda za opću i anorgansku kemiju Prirodoslovno-matematičkog fakulteta Sveučilišta u Zagrebu, Zavod za opću i anorgansku kemiju, Zagreb, 2002., str. 20-26.

32. D. Grdenić, Povijest kemije, Novi Liber i Školska knjiga, Zagreb, 2001., str. 900.

33. D. Grdenić, Atomi i molekule, Mala naučna knjižnica Hrvatskog prirodoslovnog društva, 7-8, Nakladni zavod Hrvatske, Zagreb, 1946., str. 3.

34. D. Grdenić, Modeli molekula, Mala biblioteka za matematiku, fiziku i kemiju, Školska knjiga, Zagreb, 1950.

35. P. Kalinovčić, Molekulski modeli: izrada modela s magnetima, Kem. Ind. 64 (7-8) (2015) 399-402, doi: https://doi. org/10.15255/KUI.2015.023

36. N. Raos, Prvih pet godina, u: N. Raos (ur.), IMI očima suradnika, Institut za medicinska istraživanja i medicinu rada, Zagreb, 1999., str. 96-104.

37. B. Kamenar, Znanstveni rad Zavoda, u: I. Vicković (ur.), 50 godina Zavoda za opću i anorgansku kemiju Prirodoslovno-matematičkog fakulteta Sveučilišta u Zagrebu, Zavod za opću i anorgansku kemiju, Zagreb, 2002., str. 75-104.

38. N. Raos, Kemijska veza u hrvatskim udžbenicima, Kem. Ind 65 (3-4) (2016) 147-152, doi: https://doi.org/10.15255/ KUI.2015.012.

39. D. Grdenić, Divovske molekule, Knjižnica "Prirode" Hrvatskog prirodoslovnog društva, sv. 17, Nakladni zavod Hrvatske, Zagreb, 1948. 


\title{
SUMMARY
}

\section{“Models of Molecules" by Drago Grdenić and the Beginnings of Structural Chemistry in Croatia}

\author{
Nenad Raos
}

The beginning of structural chemistry in Croatia can be placed in the year of 1948 when Drago Grdenić (1919-2018) finished his postgraduate study at Moscow University (visiting Nesmeyanov and Kitaigorsky) and in 1952 founded the Department of General and Inorganic Chemistry at the Faculty of Science, University of Zagreb. The research field of Professor Grdenić and his Department was primarily the structural chemistry of mercury compounds, and that of coordination compounds of molybdenum and vanadium, as well as of organic compounds, including macrolide antibiotic azithromycin and its derivatives (in cooperation with PLIVA pharmaceutical company). Special emphasis is given to Grdenić's book "Modeli molekula" (Models of Molecules), published in 1950, that was initially written as a handbook for the use of Stuart models, produced by the Zagreb company Učila, but turned out to be an extensive, but popular introduction into atomic theory, stereochemistry and structural chemistry. Thus, the book paved the way of modern chemistry to Croatian schools.

\section{Keywords}

Drago Grdenić, Dorothy C. Hodgkin, Zagreb University, Stuart molecular models, X-ray analysis

Institute for Medical Research

Review

and Occupational Health

Received September 24, 2019

Ksaverska c. 2

10000 Zagreb, Croatia

Accepted November 17, 2019 